\title{
Proximal glomerulo-tubular balance in patients with Type 1 (insulin-dependent) diabetes mellitus
}

\author{
J. Brøchner-Mortensen ${ }^{1}$, M.Støckel ${ }^{1}$, P.J.Sørensen ${ }^{2}$, A. H. Nielsen ${ }^{3}$ and J. Ditzel ${ }^{2}$ \\ ${ }^{1}$ Department of Clinical Physiology, and Sections of ${ }^{2}$ Endocrinology and ${ }^{3}$ Nephrology, Department of Medicine, Aalborg Hospital, Denmark
}

\begin{abstract}
Summary. To evaluate the glomerulo-tubular balance of sodium and water in the proximal tubules of diabetic patients with elevated glomerular filtration rate, the renal plasma clearance of lithium and the glomerular filtration rate $\left({ }^{51} \mathrm{Cr}\right.$ EDTA plasma clearance) were determined simultaneously in 11 ambulatory Type 1 (insulin-dependent) diabetic patients (aged 25-35 years) with no evidence of diabetic nephropathy and in 10 age-matched healthy subjects. The renal plasma clearance of lithium, which is a measure of flow from the proximal tubule into the thin descending limb of the loop of Henle, did not differ between diabetic and control subjects $\left(28.9 \pm 4.0\right.$ versus $28.3 \pm 5.1 \mathrm{ml} / \mathrm{min}$ per $1.73 \mathrm{~m}^{2}$ surface area, mean $\pm S D$ ), whereas the glomerular filtration rate in the diabetic patients was significantly higher than in the control sub-
\end{abstract}

jects $\left(136 \pm 10.2\right.$ versus $108 \pm 13.6 \mathrm{ml} / \mathrm{min}$ per $1.73 \mathrm{~m}^{2}, p<$ $0.001)$. The same held true for the fractional reabsorption rate in the proximal tubules $(78.7 \pm 3.2$ versus $73.6 \pm 4.9 \%, p<$ 0.02 ). The results indicate that the elevation of the glomerular filtration rate in diabetic patients is associated with a parallel increase in the proximal reabsorption rate. This type of glomerulo-tubular balance implies that the flow of water and flux of sodium to the segments distal to the proximal tubule are kept constant during variations in the glomerular filtration rate.

Key words: Type 1 diabetes, glomerulo-tubular balance, glomerular filtration rate, lithium clearance.
It is well-established that the glomerular filtration rate (GFR) is increased significantly in Type 1 diabetic patients before the onset of clinical nephropathy [1-5]. Similar results have been reported in insulin-treated streptozotocin/alloxan-diabetic rats [6-8] in which the elevation of whole kidney GFR reflects an increase of GFR in the single nephron.

As known from micropuncture studies in animals, the general feature of the relationship between GFR and reabsorption of sodium and water in the proximal tubule is a proportionality between changes of these measures both under physiological and several pathophysiological conditions [9-13]. This glomerulo-tubular balance implies that the flow of water and flux of sodium into the thin descending limb of the loop of Henle is kept fairly constant over a wide range of GFR-variation [14].

Several reports within the last few years have shown that the renal plasma clearance of lithium is a reliable measure of flow from the straight part of the proximal tubule into the thin descending limb of the loop of Henle [15-17]. From simultaneous determination of GFR and the renal plasma clearance of lithium, it has thus become possible to assess the relationship between
GFR and proximal reabsorption in man. In the present study we have determined this relationship in Type 1 diabetic patients and compared the results with those obtained from a group of age-matched control subjects. The aim of the study was to investigate whether the glomerulo-tubular balance for sodium and water in the proximal tubule is preserved in diabetic patients with elevated GFR.

\section{Subjects and methods}

\section{Subjects}

Fourteen ambulatory Type 1 diabetic patients (two females, 12 males) and 13 age-matched healthy staff-members (two females, 11 males) gave their informed written consent to the study, which was approved by the local Ethical Research Committee. Due to hypoglycaemia during the investigation and/or incomplete bladder emptying (judged from creatinine clearance determined twice), a total of six subjects were excluded leaving 11 diabetic patients (one female, 10 males) and ten healthy subjects (all men). Clinical data for the 21 individuals are given in Table 1 . None of the patients had proteinuria when tested with Albustix and all had a serum creatinine concentration within normal limits. None received any medication besides insulin.

In the evening before the study each participant was given $16.2 \mathrm{mmol}$ of lithium $\left(\mathrm{Li}_{2} \mathrm{CO}_{3}\right)$ orally. Until the end of the investiga- 
Table 1. Clinical data in 11 diabetic patients and 10 healthy subjects

\begin{tabular}{|c|c|c|c|c|c|c|c|c|}
\hline Subjects & $\begin{array}{l}\text { Age } \\
\text { (years) }\end{array}$ & $\begin{array}{l}\text { Duration of } \\
\text { diabetes } \\
\text { (years) }\end{array}$ & $\begin{array}{l}\text { Height } \\
(\mathrm{cm})\end{array}$ & $\begin{array}{l}\text { Body weight } \\
(\mathrm{kg})\end{array}$ & $\begin{array}{l}\text { Body surface } \\
\text { area } \\
\left(\mathrm{m}^{2}\right)\end{array}$ & $\begin{array}{l}\text { Mean plasma } \\
\text { glucose } \\
(\mathrm{mmol} / \mathrm{l})\end{array}$ & $\begin{array}{l}\text { Mean urinary } \\
\text { glucose } \\
(\mathrm{mmol} / \mathrm{h})\end{array}$ & $\begin{array}{l}\text { Insulin } \\
\text { requirement } \\
(\mathrm{U} / 24 \mathrm{~h})\end{array}$ \\
\hline 1 & 33 & 0.5 & 177 & 67.8 & 1.84 & 13.4 & 9.5 & 12 \\
\hline 2 & 34 & 1 & 182 & 73.4 & 1.94 & 10.1 & 0.4 & 24 \\
\hline $3^{a}$ & 29 & 1 & 172.5 & 69.5 & 1.82 & 11.9 & 4.0 & 32 \\
\hline 6 & 35 & 8 & 175.5 & 66.3 & 1.81 & 10.2 & 16.4 & 36 \\
\hline 7 & 31 & 5 & 182 & 63.5 & 1.82 & 13.9 & 3.5 & 44 \\
\hline 8 & 29 & 4 & 182 & 77 & 1.98 & 13.8 & 3.2 & 52 \\
\hline 9 & 25 & 24 & 174 & 72 & 1.86 & 9.9 & 1.3 & 52 \\
\hline 10 & 32 & 17 & 176 & 64.5 & 1.79 & 10.9 & 2.2 & 40 \\
\hline 11 & 31 & 21 & 178 & -82.3 & 2.00 & 7.8 & 0.6 & 72 \\
\hline \multicolumn{9}{|c|}{ Normal subjects } \\
\hline 2 & 36 & & 180 & 81.8 & 2.02 & 5.8 & & \\
\hline 3 & 31 & & 176 & 71.5 & 1.87 & 5.5 & & \\
\hline 4 & 35 & & 191 & 78 & 2.06 & 6.1 & & \\
\hline 5 & 26 & & 181 & 76.3 & 1.96 & 5.9 & & \\
\hline 6 & 30 & & 182 & 94.5 & 2.16 & 4.9 & & \\
\hline 7 & 33 & & 174 & 65.5 & 1.79 & 5.9 & & \\
\hline 8 & 36 & & 190 & 105 & 2.33 & 6.5 & & \\
\hline 9 & 34 & & 182 & 64.8 & 1.84 & 5.5 & & \\
\hline 10 & 27 & & 184 & 84.3 & 2.07 & 5.5 & & \\
\hline Mean \pm SD & $32.1 \pm 3.5$ & & $182 \pm 5.4$ & $78.9 \pm 13.1$ & $2.00 \pm 0.17$ & $5.6 \pm 0.5$ & & \\
\hline
\end{tabular}

a Female

tion the next day, no drink containing methylxantine was allowed. The subjects were not fasting and the diabetic patients had their usual doses of insulin. On the day of investigation, the first clearance period was started at $08.00 \mathrm{~h}$ followed by a second period from 10.45 to $12.45 \mathrm{~h}$. During examination all subjects were in the supine position (only briefly standing or sitting during voiding of urine), and $300 \mathrm{ml}$ of tap-water was given by mouth every hour. Venous blood samples for analysis of glucose, sodium and lithium were drawn at $08.45 \mathrm{~h}$ and at the end of each clearance period.

\section{Methods}

The GFR was determined from the total ${ }^{51} \mathrm{Cr}$-EDTA plasma clearance measured by a simplified single injection method [18] with venous blood sampling 180, 200, 220 and $240 \mathrm{~min}$ after intravenous injection of $100 \mu \mathrm{Ci}{ }^{51} \mathrm{Cr}$-EDTA at $08.45 \mathrm{~h}$. The minor inaccuracy of clearance versus GFR was corrected for [19] and the thus determined GFR gives a reliable measure of the true GFR in the individual subject [20].

In each of the two clearance periods the renal plasma clearance of lithium $\left(\mathrm{Cl}_{\text {Lith }}\right)$ was calculated as the ratio between the urinary excretion rate and the interpolated serum concentration value at the middle of the clearance period after correction for delay time [21]. Lithium in serum and urine was determined by flame emission spectrophotometry. Due to background emission and ion interference from sodium, potassium and calcium, the determination of lithium in urine by flame emission photometry may give wrong results [22]. To overcome this problem a correction-matrix considering these type of errors was constructed. In urine samples covering the whole range of sodium, potassium and calcium concentrations, as measured by standard methods in the present series of healthy and diabetic subjects, the recovery of lithium was found to be $1.01 \pm 0.02$ (mean $\pm S D$; range $0.5-4.0 \mathrm{mmol} /$ 1), using the correction matrix. The range of corrected lithium concen- tration in the present study was $0.63-3.00 \mathrm{mmol} / \mathrm{l}$. There was no significant difference between $\mathrm{Cl}_{\mathrm{Lith}}$ in the two periods in the control or diabetic subjects. The precision of a single $\mathrm{Cl}_{\mathrm{Lith}}$ determination was $12 \%$ (coefficient of variation). Plasma sodium was determined by flame emission photometry on an autoanalyzer (SMA 6/90, Technicon, Tarrytown, USA). Plasma and urinary glucose were determined enzymatically by the glucose-dehydrogenase method on a single chanel autoanalyzer (Technicon).

The absolute reabsorption rate in the proximal tubules $(\mathrm{ml} / \mathrm{min})$ was determined as GFR-Cl $\mathrm{L}_{\mathrm{Lith}}$, and the fractional reabsorption rate in the proximal tubules $(\%)$ was calculated as $\left(1-\mathrm{Cl}_{\mathrm{Lith}} / \mathrm{GFR}\right) \times 100$. The distal reabsorption rate of sodium $(\mathrm{mmol} / \mathrm{h})$ was calculated as the difference between $\mathrm{Cl}_{\mathrm{Lith}}$ multiplied with the plasma sodium concentration and the urinary excretion rate of sodium, and the distal fractional reabsorption rate of sodium (\%) was determined as the absolute reabsorption rate divided by $\mathrm{Cl}_{\mathrm{Lith}}$ multiplied with the plasma sodium concentration. The results are given as the weighted mean of two determinations (one in each clearance period). The values of urinary excretion rate of sodium, GFR, $\mathrm{Cl}_{\mathrm{Lith}}$ and the absolute reabsorption rates in the proximal and distal tubules were all corrected to a standard surface area of $1.73 \mathrm{~m}^{2}$. Body surface area was estimated according to the formula of DuBois and DuBois [23]. Mann-Whitney's nonparametric test was used for comparison of mean values between diabetic and control subjects. A $p$ value $<0.05$ was considered significant.

\section{Results}

GFR in the diabetic patients was significantly increased compared with the control subjects $(136 \pm 10.2$ versus $108 \pm 13.6 \mathrm{ml} / \mathrm{min}, p<0.001$ ), whereas the renal plasma 
Table 2. GFR, renal plasma clearance of lithium $\left(\mathrm{Cl}_{\mathrm{Lith}}\right)$, reabsorption rates in proximal and distal tubules, plasma sodium concentration and urinary excretion rates in 11 diabetic patients and 10 healthy subjects

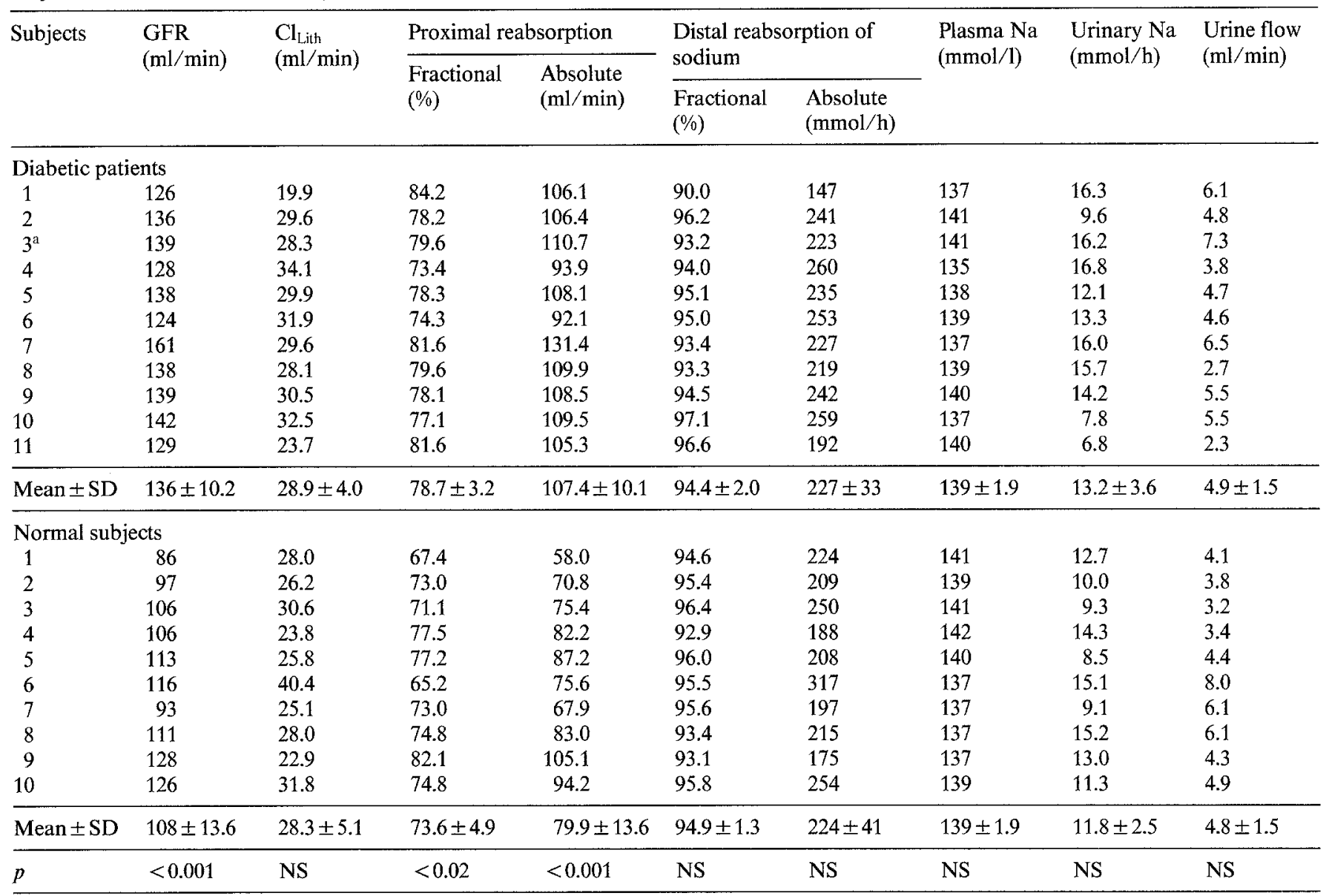

a Female

clearance of lithium $\left(\mathrm{Cl}_{\mathrm{Lith}}\right)$, did not differ between the two groups (Table 2). The fractional reabsorption rate in the proximal tubules was significantly elevated in the diabetic compared with the control subjects $(78.7 \pm 3.2$ versus $73.6 \pm 4.9 \%, p<0.02$ ), and the same held true for the absolute reabsorption rate in the proximal tubules $(107.4 \pm 10.1$ versus $79.9 \pm 13.6 \mathrm{ml} / \mathrm{min}, \quad p<0.001$, Table 2). The absolute and fractional reabsorption rate of sodium in the distal tubules, plasma sodium concentration, urinary excretion rate of sodium and urine flow did not differ between diabetic and control subjects. (Table 2)

\section{Discussion}

This study, performed in comparable groups with respect to age and body size of healthy and Type 1 diabetic adults, showed that mean GFR in the diabetic patients was significantly increased compared with the mean value in the control subjects $(28 \mathrm{ml} / \mathrm{min})$, whereas the mean flow of fluid from the proximal tubules into the thin descending limb of the loop of Henle did not differ between the two groups. These results indicate that the elevation of GFR in diabetic patients, as a group, is associated with an identical increase in the proximal reabsorption rate (the present increase being $27.5 \mathrm{ml} / \mathrm{min}$ ), and with it the proximal fractional reabsorption rate of sodium and water is elevated. This type of glomerulo-tubular balance implies that the flow of water and flux of sodium to the segments distal to the proximal tubule is kept unchanged during variations of GFR, and if at the same time the urinary excretion rate of sodium is unaltered, as in the present study, the fractional and absolute reabsorption rate of sodium in the distal tubules is also kept constant. These results differ from those reported for single-nephrons in animal studies where variations of GFR are associated with proportional but not parallel changes of the proximal tubular reabsorption rate [7, 9-13], and with it, the distal reabsorption of sodium varies to keep the final output of sodium unchanged. The results of the present study, however, concern the whole kidney in different individuals. To assess more precisely the glomerulo-tubular balance in diabetic patients, further investigations are needed with simultaneous determination of GFR and the renal plasma clearance of lithium at different levels of GFR in the same subject, e.g. in the course of strict 
insulin treatment in newly diagnosed diabetic patients during which GFR declines rapidly toward normal values $[24,25]$.

The glomerulo-tubular balance of glucose and phosphate has been studied previously in patients with Type 1 diabetes of short duration. In the study by Mogensen [26], the maximal reabsorption rate for glucose was found to be increased to the same extent as GFR, whereas the capacity for reabsorption of phosphate was depressed in relation to GFR during non-optimal control of the blood glucose level $[27,28]$. The results of these studies, and those of the present investigation, indicate that the glomerulo-tubular balance is preserved for glucose but not for phosphate, whereas it is of a special type for water and sodium in Type 1 diabetic patients with elevated GFR.

Acknowledgements. The authors wish to thank the Department of Clinical Chemistry, Aalborg Hospital for performing the chemical analysis and assistance in the determination of lithium in urine. The study was supported by a grant from the Northern Jutland Medical Research Fund.

\section{References}

1. Stalder G, Schmid R, Wolff M (1960) Funktionelle Mikroangiopathie der Nieren beim behandelten Diabetes mellitus im Kindesalter. Dtsch Med Wochenschr 85: 346-350

2. Ditzel J, Schwartz M (1967) Abnormally increased glomerular filtration rate in short-term insulin-treated diabetic subjects. Diabetes 16: 264-267

3. Mogensen CE (1971) Glomerular filtration rate and renal plasma flow in short-term and long-term juvenile diabetes mellitus. Scand J Clin Lab Invest 28: 91-100

4. Brøchner-Mortensen J (1973) Glomerular filtration rate and extracellular fluid volumes during normoglycemia and moderate hyperglycemia in diabetics. Scand J Clin Lab Invest 32: 311-316

5. Christiansen JS, Gammelgaard J, Frandsen M, Parving HH (1981) Increased kidney size, glomerular filtration rate and renal plasma flow in short-term insulin-dependent diabetics. Diabetologia 20: 451-456

6. Hostetter TH, Trou JL, Brenner BM (1981) Glomerular hemodynamics in experimental diabetes mellitus. Kidney Int 19:410-415

7. Jensen PK, Christiansen JS, Steven K, Parving HH (1981) Renal function in streptozotocin-diabetic rats. Diabetologia 21:409-414

8. Michels LD, Davidman M, Keane WF (1981) Determinants of glomerular filtration and plasma flow in experimental diabetic rats. J Lab Clin Med 98: 869-885

9. Dirks JH, Cirksen J, Berliner RW (1965) The effect of saline infusion on sodium reabsorption by the proximal tubule of the dog. $\mathbf{J}$ Clin Invest 44: 1160-1170

10. Schnermann J, Wahl M, Liebau G, Fischbach H (1969) Balance between tubular flow rate and net fluid reabsorption in the proximal convolution of the rat kidney. I. Dependency of reabsorptive net fluid flux upon proximal tubular surface area at spontaneous variations of filtration rate. Pflügers Arch Ges Physiol 304: 90-103

11. Levine DZ, Liebau G, Fischbach H, Thurau K (1968) Micropuncture studies on the dog kidney. II. Reabsorptive characteristics of the proximal tubule during spontaneous and experimental varia- tions in GFR and during drug induced natriuresis. Pflügers Arch Ges Physiol 304: 365-375

12. Rodicio J, Herrera-Acosia J, Sellman JC, Rector Jr FR, Seldin DW (1969) Studies on glomerulotubular balance during aortic constriction, ureteral obstruction and venous occlusion in hydropenic and saline-loaded rats. Nephron 6:437-456

13. Hayslett JP (1979) Functional adaptation to reduction in renal mass. Physiol Rev 59: 137-164

14. Leyssac PP (1976) The renin angiotensin system and kidney function. A review of contributions to a new theory. Acta Physiol Scand Suppl 442: 1-52

15. Thomsen K (1978) Renal handling of lithium at non-toxic and toxic serum lithium levels. Dan Med Bull 25: 106-115

16. Hayslett JP, Kashgarian M (1979) A micropuncture study of the renal handling of lithium. Pflügers Arch Ges Physiol 380: 159-163

17. Thomsen K, Holstein-Rathlou NH, Leyssac PP (1981) Comparison of three measures of proximal tubular reabsorption: lithium clearance, occlusion time, and micropuncture. Am J Physiol 214: F 348-F 355

18. Brøchner-Mortensen J (1972) A simple method for the determination of glomerular filtration rate. Scand J Clin Lab Invest 30: 271-274

19. Brøchner-Mortensen J, Rodbro P (1976) Comparison between total and renal plasma clearance of $\left[{ }^{51} \mathrm{Cr}\right]$ EDTA. Scan J Clin Lab Invest 36: 247-249

20. Brøchner-Mortensen J (1978) Routine methods and their reliability for assessment of glomerular filtration rate in adults - with special reference to total $\left[{ }^{51} \mathrm{Cr}\right]$ EDTA plasma clearance. Dan Med Bull 25: 181-202

21. Nosslin B (1965) Determination of clearance and distribution volume with the single injection technique. Acta Med Scand Suppl 442: $97-101$

22. Amdisen A (1975) The estimation of lithium in urine. In: Johnson FN (ed) Lithium research and therapy. Academic Press, London, New York, San Francisco, pp 181-195

23. DuBois D, DuBois F (1916) A formula to estimate the approximate surface area if height and weight be known. Arch Intern Med 17:863-871

24. Mogensen CE, Andersen MJF (1975) Increased kidney size and glomerular filtration rate in untreated juvenile diabetics: normalization by insulin treatment. Diabetologia 11: 221-224

25. Christiansen JS, Gammelgaard J, Tronier B, Svendsen PAa, Parving HH (1982) Kidney function and size in diabetics before and during initial insulin treatment. Kidney Int 21: 683-688

26. Mogensen CE (1971) Maximum tubular reabsorption capacity for glucose and renal hemodynamics during rapid hypertonic glucose infusion in normal and diabetic subjects. Scand J Clin Lab Invest 28: 101-109

27. Gertner JM, Tamborlane WV, Horst RL, Sherwin RS, Feling P, Genel M (1980) Mineral metabolism in diabetes mellitus: changes accompanying treatment with a portable subcutaneous insulin infusion system. J Clin Endocrinol Metab 50: 862-866

28. Ditzel J, Brøchner-Mortensen J, Kawahara R (1982) Dysfunction of tubular phosphate reabsorption related to glomerular filtration and blood glucose control in diabetic children. Diabetologia 23: $406-410$

Received: 21 April 1983

and in revised form: 9 March 1984

Dr. J. Brøchner-Mortensen

Department of Clinical Physiology

Aalborg Hospital

DK-9000 Aalborg

Denmark 